\title{
Deletion of the thrombin cleavage domain of osteopontin mediates breast cancer cell adhesion, proteolytic activity, tumorgenicity, and metastasis
}

\author{
Michel S Beausoleil ${ }^{1,3}$, Erika B Schulze ${ }^{3}$, David Goodale ${ }^{3}$, Carl O Postenka ${ }^{3}$, Alison L Allan ${ }^{1,2,3,4^{*}}$
}

\begin{abstract}
Background: Osteopontin (OPN) is a secreted phosphoprotein often overexpressed at high levels in the blood and primary tumors of breast cancer patients. OPN contains two integrin-binding sites and a thrombin cleavage domain located in close proximity to each other.

Methods: To study the role of the thrombin cleavage site of OPN, MDA-MB-468 human breast cancer cells were stably transfected with either wildtype OPN (468-OPN), mutant OPN lacking the thrombin cleavage domain (468- $\triangle \mathrm{TC})$ or an empty vector (468-CON) and assessed for in vitro and in vivo functional differences in malignant/ metastatic behavior.

Results: All three cell lines were found to equivalently express thrombin, tissue factor, CD44, $\alpha \vee \beta 5$ integrin and $\beta 1$ integrin. Relative to 468-OPN and 468-CON cells, 468- $\triangle T C$ cells expressing OPN with a deleted thrombin cleavage domain demonstrated decreased cell adhesion $(p<0.001)$, decreased mRNA expression of MCAM, maspin and TRAIL ( $p<0.01$ ), and increased UPA expression and activity $(p<0.01)$ in vitro. Furthermore, injection of 468- $\triangle$ TC cells into the mammary fat pad of nude mice resulted in decreased primary tumor latency time $(p<0.01)$ and increased primary tumor growth and lymph node metastatic burden $(p<0.001)$ compared to 468-OPN and 468-CON cells.

Conclusions: The results presented here suggest that expression of thrombin-uncleavable OPN imparts an early tumor formation advantage as well as a metastatic advantage for breast cancer cells, possibly due to increased proteolytic activity and decreased adhesion and apoptosis. Clarification of the mechanisms responsible for these observations and the translation of this knowledge into the clinic could ultimately provide new therapeutic opportunities for combating breast cancer.
\end{abstract}

\section{Background}

Breast cancer is a leading cause of cancer death in women, mainly due to metastasis of the disease to distant organs. How the process of metastasis occurs, and what biological factors may contribute to it, is an important field of research being undertaken. It is believed that with improved understanding of the biology of the disease we can develop new diagnostic, prognostic and

\footnotetext{
* Correspondence: alison.allan@lhsc.on.ca

'Department of Anatomy \& Cell Biology, Schulich School of Medicine and Dentistry, University of Western Ontario, (1151 Richmond Street), London Ontario, (N6A 3K7), Canada

Full list of author information is available at the end of the article
}

therapeutic methods. The current study is focused on examining the interaction of two such factors; thrombin and osteopontin (OPN).

OPN has been clinically associated with many types of human cancer [1-10]. Specifically in breast cancer patients with metastatic disease, elevated levels of baseline OPN in plasma have been linked to poor prognosis $[11,12]$. Other studies have found that changes in OPN plasma level over time after therapy are associated with clinical outcome [13]. Experimentally, OPN has been functionally associated with growth, survival, adhesion, migration, invasion, angiogenesis and metastasis of

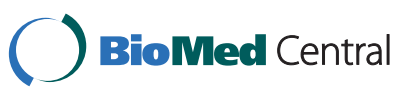


breast cancer cells [14-24]. Furthermore, OPN has been shown to interact with cell surface receptors (integrins, CD44) $[15,19,21,25]$, secreted proteases (urokinase plasminogen activator, thrombin) $[17,24]$ and growth factor/ receptor pathways (EGFR, Met) $[16,18]$ in order to exert its malignancy-promoting effects.

OPN has many protein interaction domains which are thought to play a role in the function of the protein. These include two integrin binding sites (RGD [arginine $\mathrm{e}^{159}$ - aspartic acid ${ }^{161}$ ] and SVVYLR [serine ${ }^{162}$ arginine ${ }^{168}$ ]; a CD44 binding domain; and a thrombin cleavage domain (RSK [arginine ${ }^{168}$-lysine ${ }^{170}$ ]) [26]. When OPN is cleaved at the RSK site by thrombin, it is separated into two approximately equivalent sized pieces, including $\mathrm{N}$-terminal and $\mathrm{C}$-terminal fragments [27]. Thrombin itself is a secreted serine protease found in the blood and an integral protein in the processes of haemostasis and coagulation [28]. Thrombin is activated upstream by tissue factor (TF) which is exposed on the surface of endothelial cells after injury, but is also often overexpressed on the surface of cancer cells [29]. The tumor microenvironment thus provides a rich environment for abundant activation of thrombin and therefore OPN cleavage.

The effect of OPN cleavage by thrombin has been previously studied by ourselves and others $[24,27,30,31]$. Senger et al. [27], demonstrated that when OPN is cleaved by thrombin, in vitro adhesion and migration of cancer cells is increased, specifically due to the $\mathrm{N}$-terminal domain of OPN, possibly by increasing access to the integrin binding domains $[27,30]$. However, work by Mi et al. [31] observed that it is the C-terminal domain of thrombin-cleaved OPN that increases both migration and adhesion of breast cancer cells. This C-terminal effect occurs by complexing with cyclophilin C and binding of CD147 on the cell surface [31]. Our laboratory has previously shown that blockage of thrombin activity using Argatroban (a clinically used thrombin inhibitor) specifically reduced adhesion and migration of MDA-MB-468 breast cancer cells transfected with OPN (468-OPN) but had no effect on control cells (468-CON) [24]. Furthermore, Argatroban treatment of tumor-bearing mice reduced primary tumor growth, lymphovascular invasion, and lymph node metastasis using both OPN-dependent and OPN-independent mechanisms [24]. This data from our lab clearly shows that pharmacologic inhibition of thrombin activity can reduce OPN-mediated metastatic behavior. However, the specific biochemical interaction between thrombin and osteopontin and its role in mediating breast cancer cell malignancy requires further elucidation.

In the current study, we investigated the biochemical and functional relationship between OPN and thrombin during breast cancer metastasis using the 468-CON and 468-OPN human breast cancer cell lines, as well as a third cell line (468- $\Delta \mathrm{TC})$ which expresses a mutant OPN lacking the thrombin cleavage domain. In doing this, we hoped to identify those effects of OPN that were due to its direct thrombin cleavage rather than effects simply related to pharmacological inhibition of host- and/or tumor cell-produced thrombin. We hypothesized that deletion of the thrombin cleavage site on the OPN protein backbone would alter the ability of OPN to mediate breast cancer malignancy and metastasis. Unexpectedly, the novel findings presented here indicate that breast cancer cells expressing thrombinuncleavable OPN demonstrate enhanced metastatic behavior in vitro and in vivo relative to cells expressing wildtype OPN.

\section{Methods \\ Cell Culture}

The tumorigenic, weakly metastatic MDA-MB-468 human breast cancer cell line (a kind gift from Dr. Janet Price, University of Texas, M.D. Anderson Cancer Center, Houston, TX) was maintained in aMEM medium (Invitrogen; Carlsbad, CA) supplemented with 10\% fetal bovine serum (FBS, Sigma Chemical Company; St. Louis, MO) at $37^{\circ} \mathrm{C}$ in a humidified $\mathrm{CO}_{2}$ incubator.

\section{Plasmids \& Transfection}

Stable transfection of MDA-MB-468 human breast cancer cells was carried out using liposome-based transfection as described previously ([21]. Plasmids for transfections included an unmodified pcDNA3 control plasmid (Invitrogen); a wildtype OPN expression vector that was previously generated by cloning the full-length human OPN cDNA (from plasmid OP-10) into pcDNA3 [32,33]; and a mutant OPN expression vector in which the thrombin cleavage region $\left({ }^{166} \mathrm{GLRSKS}^{171}\right)$ was deleted. The thrombin-uncleavable OPN expression construct was generated by site-directed mutagenesis of the wildtype OPN expression plasmid using a 49 mer mutagenic oligonucleotide specific for introducing the thrombin cleavage deletion $(\triangle \mathrm{TC})\left(5^{\prime}\right.$ GGATGTCAGGTCTGCGAAACTTCTTATAAACCACACTATCACCT CGGCC 3'). In order to control for clonal heterogeneity, pooled populations were created by combining several clonal cell populations that resulted from the stable transfections. The specific cell populations generated included a control vector-transfected MDA-MB-468 pooled population consisting of 6 clones (468-CON), an OPN-transfected MDA-MB-468 pooled population consisting of 6 clones (468-OPN) [21] and a $\triangle \mathrm{TC}-\mathrm{OPN}$-transfected MDA-MB-468 pooled population consisting of 6 clones (468- $\Delta \mathrm{TC})$. To maintain stable transgene expression, cell lines were maintained under 
selective pressure using $500 \mu \mathrm{g} / \mathrm{ml}$ of active Geneticin (G418-sulfate, Invitrogen).

\section{Western Blot Analysis}

Cells were plated at $10^{6}$ cells $/ 100 \mathrm{~mm}$ plate, grown for 48 hrs and media was changed to Opti-MEM media (Invitrogen). Conditioned media was collected after 18 hrs and cells were counted. For each cell line, a normalized volume of conditioned media equivalent to $5 \times 10^{5}$ cells was subjected to electrophoresis in $10 \%$ SDSpolyacrylamide gels and transferred onto polyvinylidene difluoride membranes (Immobilon ${ }^{\mathrm{TM}}$, Millipore; Bedford, MA). After transfer, gels were stained with Coomassie Blue to confirm equal loading and transfer efficiency. Primary antibodies included a sheep polyclonal antihuman antibody against tissue factor (TF, Cedarlane Laboratories; Burlington, ON, 1:2000 dilution), a mouse monoclonal anti-human antibody against thrombin (clone 12, BD Biosciences; Franklin Lakes, NJ, 1:1000 dilution), and a rabbit monospecific polyclonal antihuman antibody against OPN (hOPN1; $7.5 \mu \mathrm{g} / \mathrm{ml}$ ), a kind gift from Dr. Toshi Uede, Hokkaido University, Sapporo, Japan [34]. The secondary antibodies used were anti-sheep (TF), anti-mouse (thrombin) (Sigma) or anti-rabbit (OPN) (GE Healthcare, Little Chalfont Buckinghamshire, UK) HRP conjugates (1:2000 dilution). The blocking/dilution reagent used was $5 \%$ skim milk in TBST (Tris-buffered saline $+0.05 \%$ Tween-20). Thrombin, TF, and OPN protein expression was visualized using an enhanced chemiluminescence system (Roche Applied Sciences; Laval, QC).

\section{Flow Cytometry Analysis}

Cells were grown to $\sim 80 \%$ confluence in normal media and harvested by gentle trypsinization. Flow cytometry analysis of cell surface receptors was carried out using the appropriate primary antibodies against integrins: $\beta_{1}$, $\beta_{3}, \alpha_{v} \beta_{5}, \alpha_{9} \beta_{1}$, (Chemicon) or IgG (negative isotype control) $\left(1 \mu \mathrm{g} / 10^{6}\right.$ cells) (Cedarlane, Mississauga, ON) for $1 \mathrm{hr}$ at $4^{\circ} \mathrm{C}$ and phycoerytherin (PE)-labeled secondary antibody (BD Biosciences, Franklin Lakes, NJ) for $1 \mathrm{hr}$ in the dark. Samples were run on a Beckman Coulter EPICS XL-MCL flow cytometer. For CD44 expression analysis, CD44-PE and IgG-PE (negative isotype control) (BD Biosciences) antibodies were used and analyzed in a similar fashion.

\section{Cell Adhesion Assay}

Cells were plated onto sterile 96-well non-tissue culture plates (Titertek, Flow Laboratories Inc.; McLean, VA) coated with either $5 \mu \mathrm{g} / \mathrm{ml}$ of human vitronectin (VN; Sigma) or PBS (negative control), using $1 \times 10^{4}$ cells/ well in triplicate wells for each treatment. The experiment was completed three times. Vitronectin was chosen because it is a ligand for $\alpha v \beta 1$ and $\alpha v \beta 5$, two integrins that are known to interact with OPN (via the RGD region), and that are expressed by MDA-MB-468 cells. For each cell line, experiments were conducted in the presence or absence of $25 \mu \mathrm{g} / \mathrm{ml}$ Argatroban (pretreatment period of $15 \mathrm{~min}$ ) or $25 \mu \mathrm{g} / \mathrm{ml}$ integrin blocking antibodies $\left(\alpha_{\mathrm{v}} \beta_{5}\right.$ or $\left.\beta_{1}\right)$ (Chemicon, Temecula, CA). Cells were allowed to adhere for $5 \mathrm{~h}$ at $37^{\circ} \mathrm{C}$. Adhered cells were then fixed using fresh $2 \%$ gluteraldehyde/PBS and stained using Harris' hematoxylin. Blue stained cells were manually counted using a light microscope. Five high-powered fields (HPF) of view were counted for each well, and the mean number of cells per HPF were calculated and compared. Argatroban (Abbott Laboratories; North Chicago, IL) was purchased through the London Health Science Centre pharmacy.

\section{Cell Growth Assays}

Cells were plated at a density of $5.0 \times 10^{4}$ cells $/ 60 \mathrm{~mm}$ plate ( $\mathrm{n}=3$ for each time point) and maintained in regular growth media. Every $48 \mathrm{~h}$ for 12 days, triplicate cultures were trypsinized and manually counted for viable cells using a hemocytometer and trypan blue exclusion.

\section{Cell Migration Assays}

In preparation for the assay, $6.5 \mathrm{~mm}$ Transwell plates with a $8.0 \mu \mathrm{m}$ pore size (Becton Dickinson; Franklin Lakes, NJ) were pre-coated with gelatin $(6 \mu \mathrm{g} /$ well, $\mathrm{n}=3$ wells per experimental group). Media containing a chemoattractant $(10 \% \mathrm{FBS})$ or serum-free media $+0.1 \% \mathrm{BSA}$ (negative control) was added to the bottom chamber of the Transwell plates. Cell suspensions $\left(5.0 \times 10^{4}\right.$ cells/ well in serum-free growth medium $+0.1 \%$ BSA) were added to the top of the wells and allowed to incubate at $37^{\circ} \mathrm{C}$ for $24 \mathrm{~h}$. The upper portion of the transwell was removed, inverted, and fixed using fresh $1 \%$ gluteraldehyde/PBS and stained using Harris' hematoxylin. Wells were rinsed with distilled water and any non-migrated cells were carefully removed with a cotton swab. Five HPF of view were manually counted for each well, and the mean number of cells per HPF was calculated and compared.

\section{Semi-Quantitative Zymography}

Conditioned media were prepared as described in the western blot methodology. For each cell line, a normalized volume of conditioned media equivalent to $5 \times 10^{3}$ cells was subjected to electrophoresis in 10\% SDS-polyacrylamide gels supplemented with $2 \mathrm{mg} / \mathrm{ml}$ of casein and $5 \mu \mathrm{g} / \mathrm{ml}$ of plasminogen (Sigma). Gels were washed twice for 15 min each in $2.5 \%$ Triton X-100 solution to remove SDS followed by 5 washes in water. Enzymatic activity was measured after $18 \mathrm{hr}$ of incubation at $37^{\circ} \mathrm{C}$ in incubation buffer $(50 \mathrm{mM}$ Tris- $\mathrm{HCl}$ and $5 \mathrm{mM}$ 
$\left.\mathrm{CaCl}_{2}, \mathrm{pH}=7.0\right)$. Finally, gels were stained with Coomassie Blue for 1 hour and destained. White bands representing enzymatic activity were measured by densitometric analysis using a BioRad Universal Hood II and Quantity One 4.6.1 software (BioRad). Density measurements were normalized to 468-CON samples for each biological replicate and pooled for analysis.

\section{In Vivo Tumorigenicity and Metastasis Assays}

Animal research conformed to the Helsinki Declaration and to local legislation. All animal procedures were conducted in accordance with the recommendations of the Canadian Council on Animal Care, under a protocol approved by the University of Western Ontario Council on Animal Care.

Cells were prepared in sterile PBS at a concentration of $1 \times 10^{6}$ cells/100 $\mu \mathrm{l}$ and injected into the second thoracic mammary fat pad of 7-8 week-old female athymic nude $(n u / n u)$ mice as described elsewhere, using $1 \times 10^{6}$ cells/mouse and 12 mice/treatment group [21] Primary tumor growth was evaluated weekly by caliper measurement in two perpendicular dimensions, and tumor volume was estimated using the following for-

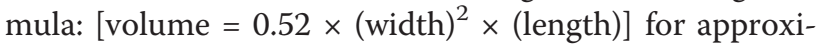
mating the volume $\left(\mathrm{mm}^{3}\right)$ of an ellipsoid. Differences in mean tumor volume were analyzed for each weekly time point.

As per previously established endpoints [21], mice were sacrificed at approximately 12 weeks post-injection and assessed for metastatic burden. Tissues and organs were examined superficially for evidence of gross macroscopic metastases at necropsy, prior to processing for histology. Primary tumors and mouse tissues collected at necropsy were fixed in 10\% neutral-buffered formalin before processing. Tissues were embedded in paraffin wax, sectioned ( $4 \mu \mathrm{m}$ thick), and subjected to standard hematoxylin and eosin (H\&E) staining. Stained slides were evaluated by light microscopy in a blinded fashion by an experienced pathologist in order to observe histopathological characteristics and to identify regions of micrometastatic involvement. Color RGB (Red Green Blue) images were taken using an Olympus ${ }^{\odot}$ microscope (Olympus America, Center Valley, PA) and regions of micrometastatic involvement were manually outlined. Metastatic tumor burden in the lymph node (tumor area/organ total area) was determined quantitatively using ImageJ analysis software (NIH). Color images were converted to 8-bit images and thresholding was performed on each picture to obtain a black (manually outlined total organ tissue or total tumor tissue) and white (background) image. Quantification was done using the 'analyze particles' option of the ImageJ software after the scale had been set for the microscope objective used.

\section{RNA Extraction and Quantitative Real-Time PCR}

Cells were grown on $60 \mathrm{~mm}$ diameter dishes until $~ 80 \%$ confluence (3 dishes/cell line) and total RNA was collected using the TRIzol ${ }^{\circledR}$ Reagent (Invitrogen) system as per the manufacturer's protocol. Total RNA was quantified by spectrophotometry, assuming an absorbance (at $260 \mathrm{~nm}$ ) of 1.0 equal to $40 \mu \mathrm{g}$ RNA/mL. cDNA was created from $1 \mu \mathrm{g}$ of total RNA using SuperScript III Reverse transcriptase, oligo(dt)20 primers, $10 \mathrm{mM}$ dNTP Mix, 5× Strand Buffer, 0.1 M DTT and RNase out (Invitrogen). Reverse transcription (no SuperScript III) were run with every reaction group.

Real-time PCR was conducted with a Rotor-Gene 3000 temperature cycler (Corbett Research, San Francisco, CA) using cDNA as a template and Brilliant ${ }^{\circledR}$ SYBR $^{\circledR}$ Green QPCR Master Mix (Stratagene), following the manufacturer's protocol. Expression was normalized to glyceraldehyde 3-phosphate dehydrogenase (GAPDH) internal control and further compared to the 468-CON cell line. Reverse transcription (no SuperScript III) and non template (no cDNA) controls were run with every reaction to ensure that genomic DNA was not amplified and the reagents were not contaminated. Primers used: GAPDH [Forward 5'-CATGTTCGT CATGGGTGTGAACCA-3', Reverse 5'-ATGGCATGGACTGTGGTCATGAGT-3']; uPA [Forward 5'-CAGGGCATCTCCTGTGCATG-3', Reverse 5'-AGCCCTG CCCTGAAGTCGTTA-3']; MCAM [Forward 5'-GGGTACCCCATTCCTCAAGT-3', Reverse 5'-CCTGGACTCCTTCATGTGGT-3']; Maspin (SERPINB5) [Forward 5'-CTACTTTGTTGGCAAGTGG ATGAA-3', Reverse ACTGGTTTGGTGTCTGTC TT GTTG-3']; and TRAIL (TNFSF10) [Forward 5'-CGT GTACTTTACCAACGAG CTGA-3', Reverse 5'-ACGGAGTTGCCACTTGACTTG-3’].

\section{Statistical Analysis}

All in vitro experiments were performed at least in triplicate, and data were compiled from 3 separate experiments. In vivo studies were carried out using multiple animals ( $\mathrm{n}=12$ per experimental group). Statistical analysis was performed using GraphPad Prism 4.0 software $^{(}$ (San Diego, CA) using ANOVA with Tukey post hoc test (for comparison between more than two groups). Growth curve analysis was done using Prism 4.0, using non-linear regression with an F-test. In all cases, values of $\mathrm{p} \leq 0.05$ were regarded as being statistically significant.

\section{Results}

Characterization of OPN, thrombin, TF, and OPN-related receptor expression in transfected MDA-MB-468 cells

MDA-MB-468 breast cancer cells were stably transfected to overexpress either wildtype OPN (468-OPN), thrombin-uncleavable OPN (468- $\Delta \mathrm{TC})$ or an empty 
vector (468-CON) [21]. The resulting cell lines were characterized for their expression of the secreted proteins OPN, thrombin, and TF using western blot analysis (Figure 1A) and for the OPN-related receptors $\beta 1$ integrin, $\beta 3$ integrin, $\alpha v \beta 5$ integrin, $\alpha 9 \beta 1$ integrin and CD44 using flow cytometry analysis (Figure 1B).

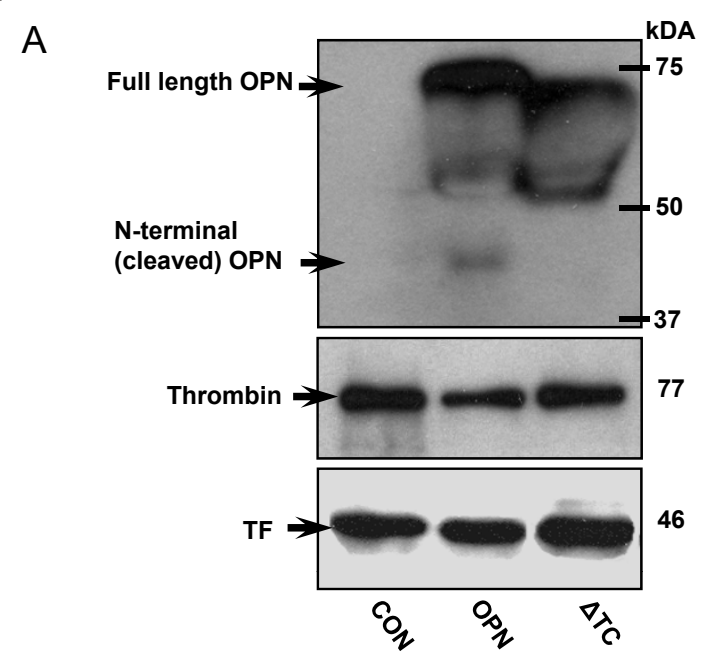

\section{B}

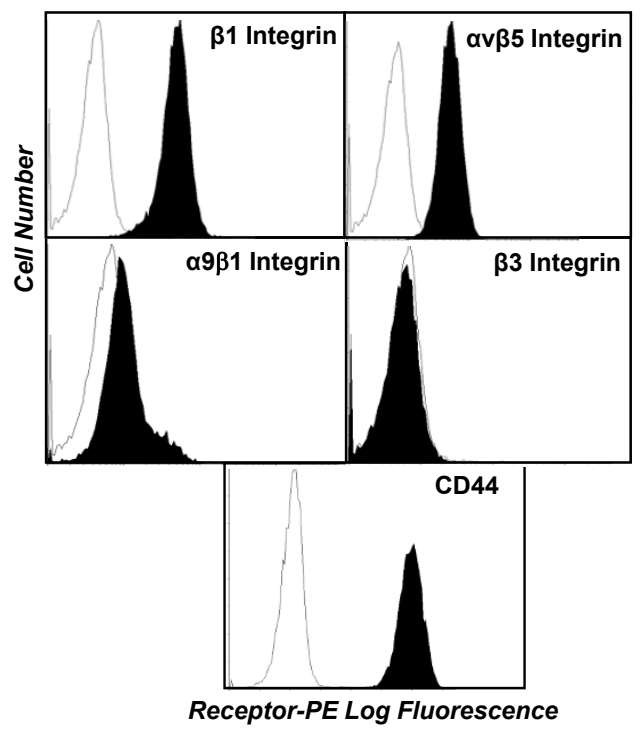

Figure 1 In vitro protein expression of OPN, thrombin, TF, and OPN-related receptors in 468-CON, 468-OPN and 468- $\triangle$ TC cells. (A) Protein expression of OPN, thrombin, and tissue factor (TF) was analyzed by western blot analysis of conditioned media from $5 \times$ $10^{5}$ cultured cells for each cell line as described in the Materials and Methods. (B) Receptor expression was measured by flow cytometry analysis. Cultured cells were incubated with specific antibodies (filled profiles) or with a nonspecific isotype control primary antibody (open profiles). Filled profiles represent expression of $\alpha 9 \beta 1$ integrin, $\beta 1$ integrin, $\beta 3$ integrin, $\alpha \vee \beta 5$ integrin and CD44. Representative results for 468-CON cells only are shown; equivalent expression was observed in all cell lines (data not shown).
All three cell lines strongly expressed both thrombin and TF at approximately equivalent levels, indicating that they would be present in the in vitro tissue culture environment during experimental assays (Figure 1A). Relative to $468-C O N$ cells, $468-\mathrm{OPN}$ and $468-\Delta \mathrm{TC}$ cells expressed high levels of OPN protein (Figure 1A). However, only the 468-OPN cells expressed the $\mathrm{N}$-terminal cleavage product of OPN, indicating that the thrombin expressed by the cells is capable of cleaving only the wildtype OPN produced by 468-OPN cells and not the thrombin uncleavable OPN produced by $468-\Delta \mathrm{TC}$ cells. In addition, the OPN expressed by the $468-\Delta \mathrm{TC}$ cells ran slightly smaller than the wildtype indicating its smaller size due to the deleted region (Figure 1A). Interestingly, we observed an additional $\sim 55 \mathrm{kDa}$ band expressed by $468-\Delta \mathrm{TC}$ cells, which may represent a novel post-translational modification.

It was also found that each cell line equivalently expressed CD44, $\alpha v \beta 5$ integrin and $\beta 1$ integrin, but not $\beta 3$ or $\alpha 9 \beta 1$ integrins. (Figure 1B). Representative results for 468-CON cells only are shown; however equivalent expression was observed in all cell lines (Additional File 1, Figure S1). Therefore any differences seen between the cell lines in subsequent experimental assays would not be due to variable receptor expression.

Deletion of the thrombin-cleavage region of OPN reduces in vitro cell adhesion of MDA-MB-468 cells

In vitro assays were carried out to measure adhesion of the cell lines to vitronectin (VN), a ligand for $\alpha v \beta 5$ and $\alpha v \beta 1$ integrins expressed by the MDA-MB-468 cells. Treatments consisted of Argatroban (thrombin inhibitor, $25 \mu \mathrm{g} / \mathrm{ml}), \beta 1$ or $\alpha \mathrm{v} \beta 5$ integrin blocking antibodies, or IgG (negative control) $(25 \mu \mathrm{g} / \mathrm{ml})$. Interestingly, the 468 OPN cells exhibited significantly increased adhesion compared to $468-\mathrm{CON}$ and $468-\Delta \mathrm{TC}$ cells $(\mathrm{p}<0.001)$, whereas the $468-\Delta \mathrm{TC}$ cells demonstrated significantly decreased adhesion compared to both 468-CON and 468-OPN cells $(\mathrm{p}<0.001)$ (Figure 2$)$. The increased adhesion in 468-OPN cells was dependant on thrombin cleavage as evidenced by the significant decrease of these behaviors when treated with the thrombin inhibitor Argatroban $(\mathrm{p}<0.05)$. Treatment with $\beta 1$ or $\alpha \mathrm{v} \beta 5$ blocking antibodies also significantly decreased adhesion of 468-OPN cells ( $\mathrm{p}<0.05)$, whereas the IgG isotype control antibody had no effect. Argatroban and integrin blocking antibodies had no effect on $468-\Delta \mathrm{TC}$ cell adhesion.

No difference was observed between 468-CON, 468-OPN, and 468- $\triangle \mathrm{TC}$ cell lines with regards to cell proliferation in vitro (Additional File 2, Figure S2A). Although we did observe that both 468 -OPN and $468-\Delta \mathrm{TC}$ were significantly more migratory relative to 468-CON cells, there was no significant difference in 


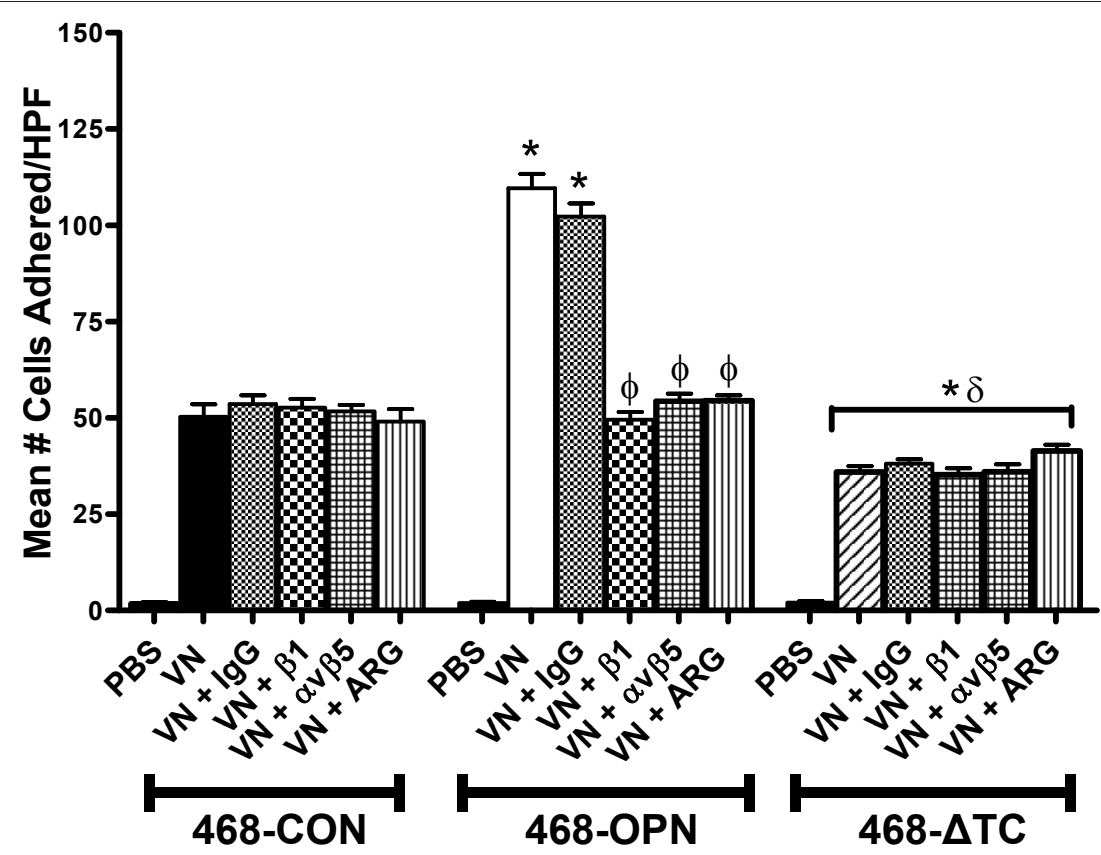

Figure 2 In vitro cell adhesion of 468-CON, 468-OPN and 468- $\Delta$ TC cells. 96 well plates were pre-coated with vitronectin $(5 \mu \mathrm{g} / \mathrm{ml})$ or PBS (neg. control). $1 \times 10^{4}$ cells/well and 3 wells/treatment were plated and allowed to adhere for 5 hrs. Experiments were carried out in the presence or absence of Argatroban $(25 \mu \mathrm{g} / \mathrm{ml})$, or blocking antibodies against integrins $\beta 1$ or $\alpha \mathrm{v} \beta 5$ or lgG $(25 \mu \mathrm{g} / \mathrm{ml})$. Adhered cells were quantified by manual counting of 5 high powered fields. Data is presented as the mean +/-SEM. ${ }^{*}=$ sig. different than corresponding treatment of 468-CON ( $p<0.001) ; \delta=$ sig. different than corresponding treatment of 468-OPN ( $p<0.001)$; $\Phi=$ sig. different than respective vehicle or control $(p<0.05)$.

migration between $468-\mathrm{OPN}$ and 468- $\Delta \mathrm{TC}$ cells (Additional File 2, Figure S2B). This data is consistent with our previous studies using the 468-CON and 468-OPN cell lines [21,24].

\section{Deletion of the thrombin-cleavage region of OPN} enhances in vitro proteolytic activity of MDA-MB-468 cells To determine any proteolytic differences between the transfected cell lines, urokinase plasminogen activator (uPA) expression and activity were measured using quantitative real-time PCR and semi-quantitative zymography with subsequent densitometric analysis. The 468- $\triangle \mathrm{TC}$ cells displayed significantly increased uPA expression (Figure 3A) and activity (Figure 3B,C) relative to both the 468-CON ( $<<0.01$ ) and 468-OPN ( $\mathrm{p}<$ $0.001)$ cells. No differences in uPA expression or activity were observed between the 468-CON and 468-OPN cells.

\section{Deletion of the thrombin-cleavage region of OPN} decreases tumor latency, increase primary tumor growth, and enhances lymph node metastasis of MDA-MB-468 cells in vivo

To assess how OPN and thrombin-uncleavable OPN affect initiation and growth of primary tumors and metastases, an in vivo mouse model consisting of athymic nude $(n u /$ $n u)$ mice was used. Twelve mice per transfected cell line were injected with $1 \times 10^{6}$ cells into the mammary fat pad and tumor volume was measured weekly. With the exception of one mouse in the 468-CON group, all mice developed tumors. Initially, mice injected with both 468-OPN $(\mathrm{p}<0.05)$ and 468- $\Delta \mathrm{TC}(\mathrm{p}<0.001)$ cells grew significantly larger tumors than mice injected with 468-CON cells (Figure $4 \mathrm{~A})$. However, after day 42 the significant difference in tumor size between the 468-OPN and 468-CON groups was lost. At day 42 , the $468-\Delta \mathrm{TC}$ group began growing tumors significantly larger than the 468-OPN and 468CON groups $(p<0.05)$ (Figure 4A). The final mean tumor volume of the $468-\Delta \mathrm{TC}$ group was $2255.4+/-231.1 \mathrm{~mm}^{3}$; significantly larger than the 468-CON group, whose final mean tumor volume was $1066.2 \mathrm{~mm}^{3}+/-209.5(\mathrm{p}<0.01)$.

Interestingly, the mean tumor latency time (time to reach $500 \mathrm{~mm}^{3}$ ) was significantly shorter for the 468 $\Delta \mathrm{TC}$ group compared to both the 468-CON $(\mathrm{p}<0.01)$ and 468-OPN groups $(\mathrm{p}<0.05)$ (Figure 4B). However, the rate of tumor growth (i.e. doubling time) for each group was not observed to be significantly different when analyzed using non-linear regression analysis (data not shown).

At twelve weeks post-injection mice were sacrificed and assessed for metastatic characteristics. Tissue sections from lymph nodes (LN) were subjected to H\&E 

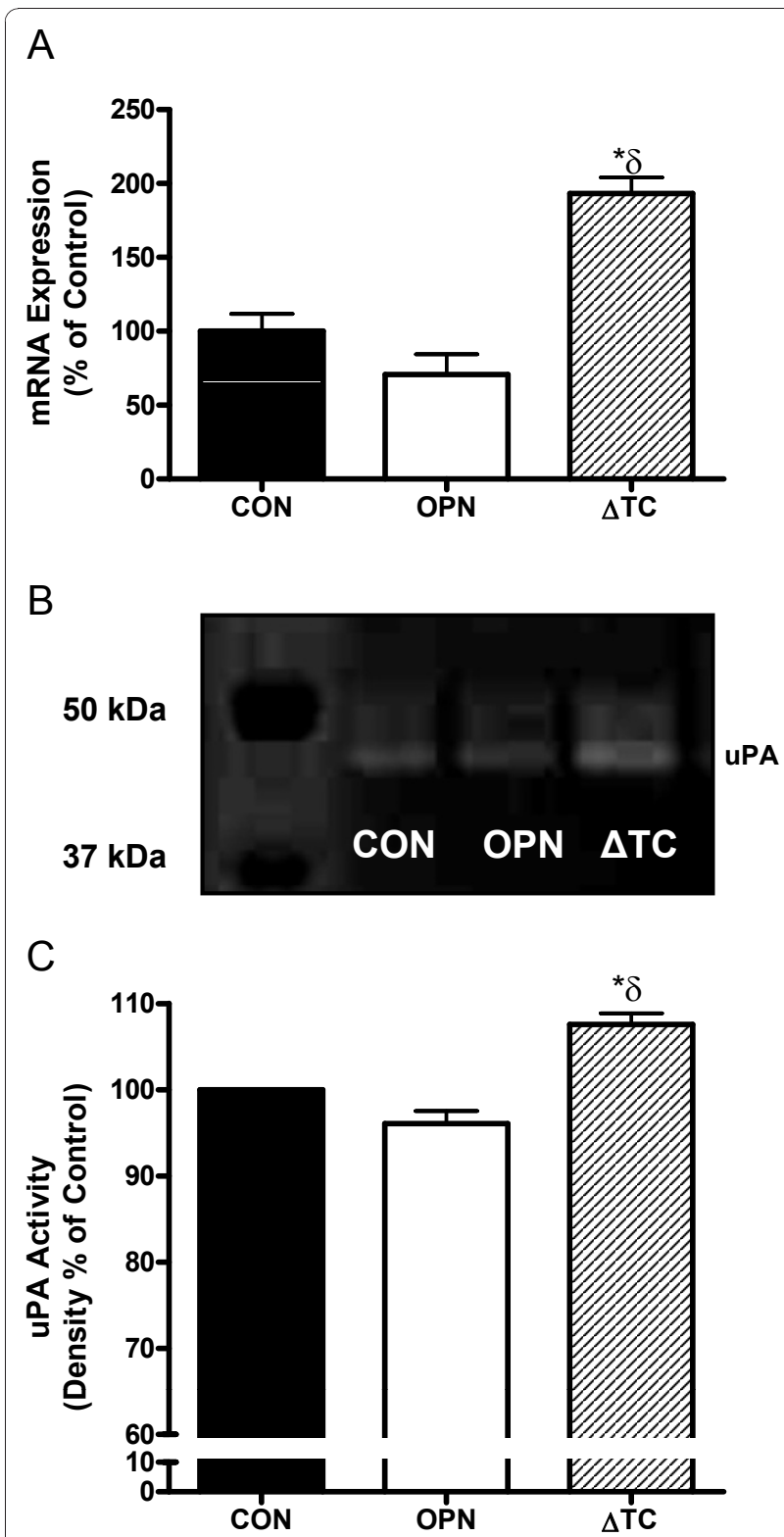

Figure 3 uPA expression and proteolytic activity of 468-CON, 468-OPN, and 468- $\triangle \mathrm{TC}$ cells. (A) Quantitative RT-PCR of UPA mRNA levels collected from cells grown on 3 separate $60 \mathrm{~mm}$ dishes over 3 experiments. Expression was adjusted to GAPDH internal control. (B) Representative gel of zymographic analysis. (C) Conditioned media equivalent to $5 \times 10^{3}$ cells was subjected to zymographic analysis and density of bands was measured using BioRad Universal Hood II and Quantity One 4.6.1 software (BioRad). Experiments were replicated 3 times. Data represents \% control of 468-CON cells and is presented as the mean $+/-$ SEM. ${ }^{*}=$ sig. different than corresponding treatment of 468-CON $(p<0.01) ; \delta=$ sig. different than corresponding treatment of 468-OPN $(p<0.001)$

staining and read by an experienced pathologist in a blinded fashion. The severity of metastasis in those lymph nodes which had been deemed positive for tumor cells was determined by measuring tumor burden.
Specifically, mean LN metastatic burden (\% of LN occupied by tumor) was calculated and showed a significantly higher burden in mice injected with 468- $\Delta \mathrm{TC}$ cells than those injected with either 468-CON or 468OPN cells $(\mathrm{p}<0.001)$ (Figure $4 \mathrm{C})$.

\section{Differential expression of MCAM, Maspin and TRAIL is consistent with the functional differences observed between $468-C O N, 468-O P N$, and $468-\triangle T C$ cells}

Finally, to identify genes potentially involved in the functional differences observed between the transfected cell lines, a preliminary gene expression analysis was undertaken using a Human Genome U133 Plus 2.0 Array (data not shown). Analysis is ongoing, however several potential genes were identified that may play a mechanistic role in the effects observed in $468-\Delta \mathrm{TC}$ cells and were subsequently validated using quantitative real-time PCR (Figure 5). Expression of the adhesion molecule MCAM was found to be significantly decreased in 468- $\triangle \mathrm{TC}$ cells compared to 468-OPN cells $(\mathrm{p}<0.01)$ (Figure 5A). This is consistent with the functional effects observed, whereby $468-\Delta \mathrm{TC}$ cells showed significantly less cell adhesion than 468-OPN cells (Figure 2). The same was true of the uPA inhibitor maspin (SERPINB5), which was significantly decreased in 468- $\triangle \mathrm{TC}$ cells compared to 468-OPN cells ( $\mathrm{p}<0.001$ ) (Figure $5 \mathrm{~B}$ ). Again, this is consistent with the increased $\mathrm{uPA}$ expression and proteolytic activity in the 468- $\Delta \mathrm{TC}$ cells observed in vitro (Figure 3 ) and the increased metastasis observed in vivo (Figure 4C). Lastly, the proapoptotic protein TNF-related apoptosis inducing ligand (TRAIL) which is encoded by the gene TNFSF10 was significantly reduced in 468- $\triangle \mathrm{TC}$ compared to control $(\mathrm{p}<0.01)$ (Figure 5C), consistent with the decreased tumor latency and increased tumor size observed in the in vivo studies (Figure 4A,B).

\section{Discussion}

The secreted phosphoprotein OPN has been shown to be both prognostically and functionally important for breast cancer progression and metastasis [11-24]. However, the mechanistic ways in which OPN exerts these effects on breast cancer cells is still not well understood. Previous studies from our lab using the direct thrombin inhibitor Argatroban suggested that thrombin activity and subsequent cleavage of OPN is important for OPN to promote cancer progression and metastasis [24]. These results were focused more on globally knocking down host and/or tumor cells thrombin activity and indirectly observing the effect on OPN cleavage. In contrast, the current study focused specifically on OPN cleavage by comparing stably transfected cell lines expressing either wildtype OPN or a mutant OPN lacking the thrombin cleavage domain. Our novel findings 


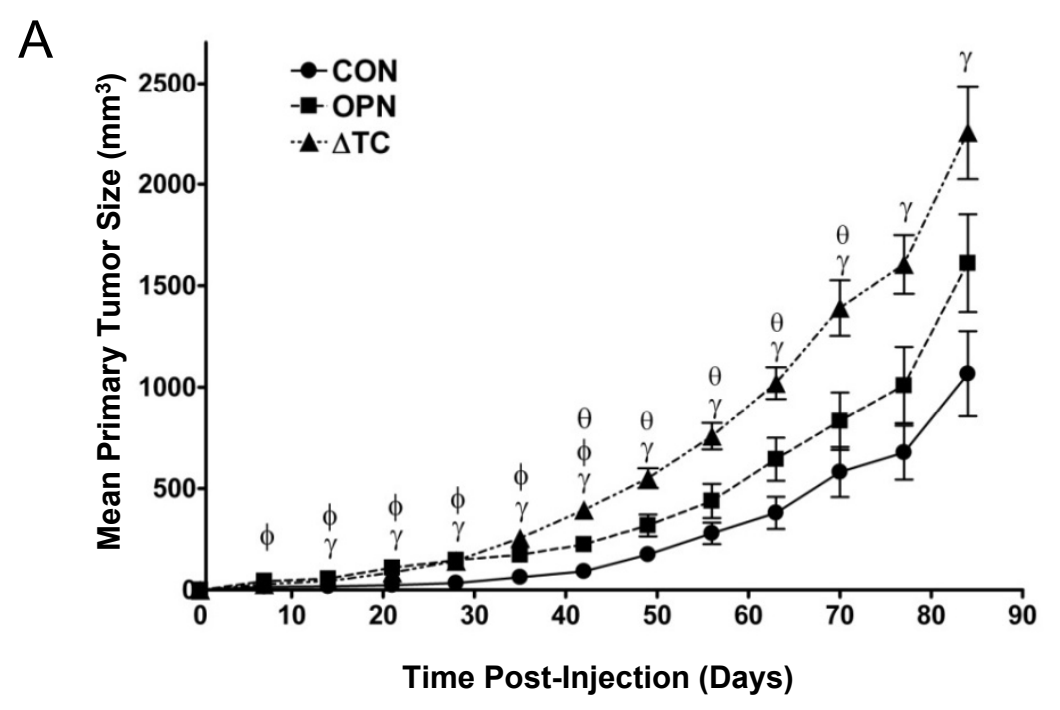

B
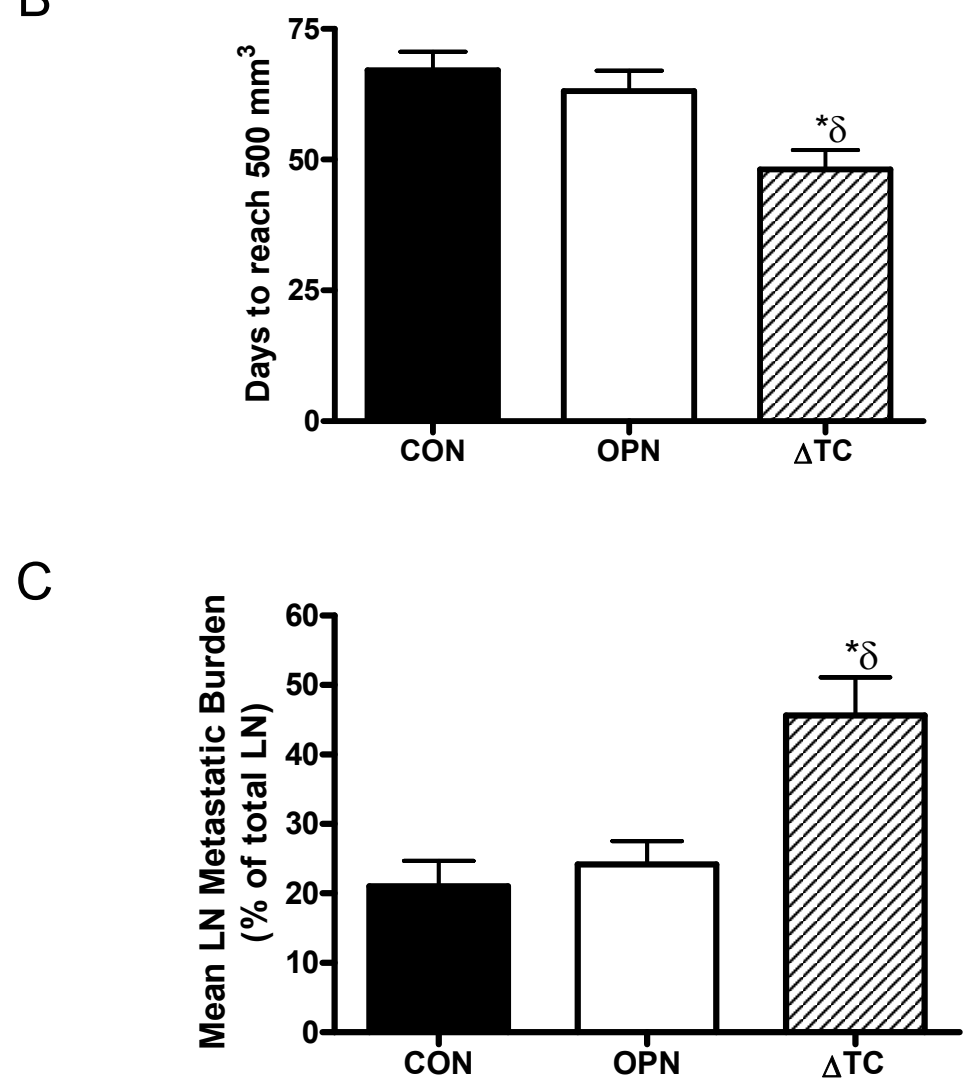

Figure 4 In vivo primary tumor growth and lymph node metastasis of 468-CON, 468-OPN and 468- $\Delta$ TC cells. (A) Transfected cell lines were injected into the mammary fat pad of female nude mice using $1 \times 10^{6}$ cells/mouse and 12 mice/group. Tumors were measured weekly in two dimensions for twelve weeks using standard calipers and the tumor volume was estimated using the formula: [volume $=0.52 \times(\text { width })^{2} \times$ (length)]. Growth data are presented as mean +/- SEM. (B) Average tumor latency (time to reach $500 \mathrm{~mm}^{3}$ ) is represented as mean +/- SEM. (C) Mean lymph node metastatic burden (\% of lymph node occupied by tumor) +/- SEM. At twelve weeks post-injection mice were sacrificed and assessed for lymph node metastasis. Tissue sections from primary lymph nodes (LN) were subjected to H\&E staining and read by an experienced pathologist in a blinded fashion. $\gamma=468-\triangle T C$ significantly different from 468-CON ( $p<0.01), \Phi=468$-OPN significantly different from 468-CON $(p<0.05), \theta=468-\triangle T C$ significantly different from 468-OPN $(p<0.05){ }^{*}=$ sig. different than corresponding treatment of $468-C O N(p<0.01) ; \delta$ $=$ sig. different than corresponding treatment of 468-OPN $(p<0.05)$. 


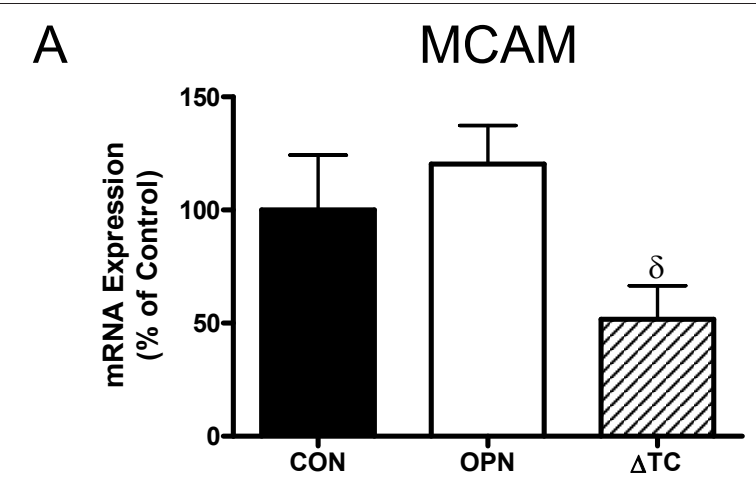

B

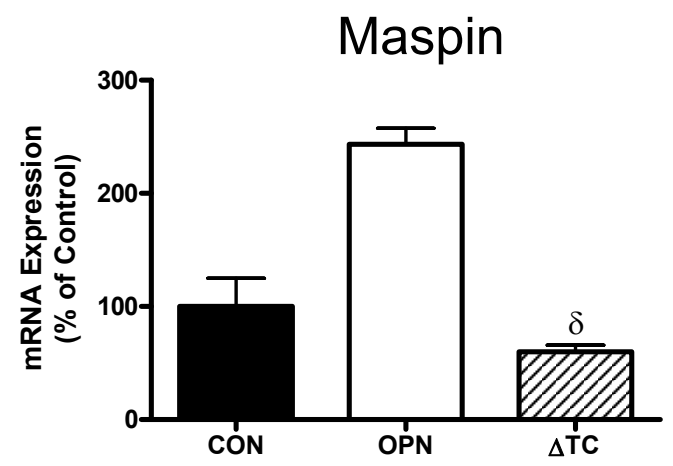

C

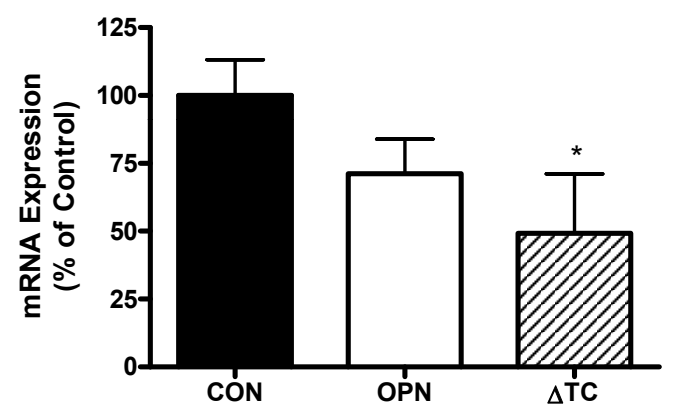

Figure 5 mRNA expression of MCAM, Maspin and TRAIL in 468-CON, 468-OPN and 468- $\Delta$ TC cells. Quantitative RT-PCR

analysis of mRNA levels collected from cells grown on 3 separate 60 $\mathrm{mm}$ dishes over 3 experiments. Expression was adjusted to GAPDH internal control. (A) MCAM, (B) Maspin, and (C) TRAIL expression are represented as $\%$ control of $468-C O N$, mean $+/$ - SEM. ${ }^{*}=$ sig. different than corresponding treatment of 468-CON $(p<0.01)$; $\delta=$ sig. different than corresponding treatment of 468-OPN $(p<0.01)$.

indicate that loss of the thrombin cleavage domain actually promotes breast cancer cell progression and metastasis both in vitro and in vivo to a level exceeding that of wildtype OPN.

Using the stably transfected cell lines 468-OPN, 468$\triangle \mathrm{TC}$ and 468-CON, we investigated how thrombin cleavage of OPN impacts breast cancer cell function using in vitro and in vivo experiments representative of behaviors important to breast cancer progression and metastasis. Each cell line was characterized for expression of various OPN-related proteins. All three cell lines equivalently expressed thrombin, TF, CD44, $\alpha \mathrm{v} \beta 5$ and $\beta 1$ integrins, therefore ensuring any differences in behavior observed were due to differences in OPN and not to differences in OPN-related proteins. It was also confirmed that the 468-OPN cell line expressed both full length and cleaved OPN, whereas the 468- $\triangle \mathrm{TC}$ cells express only the full length protein. Interestingly, we observed an additional $\sim 55 \mathrm{kDa}$ band expressed by 468 $\Delta \mathrm{TC}$ cells. Due to post-translational modifications such as glycosylation/sialation and phosphorylation, the molecular weight of OPN in monomeric form varies widely (41-75 kDa) [22]. However, the numerous forms of post-translationally modified OPN are very poorly understood, particularly with regards to their differential functional effects on cell behavior. It is possible that the additional $\sim 55 \mathrm{kDa}$ band expressed by $468-\Delta \mathrm{TC}$ cells represents a novel post-translational modification, and that this is related to the observed downstream functional effects.

In vitro analysis comparing the adhesive capabilities of the cells indicated that wildtype OPN increases adhesion of breast cancer cells whereas $\triangle \mathrm{TC}$-OPN decreases adhesion. The increased adhesion caused by wildtype OPN was specific to thrombin activity and integrin binding. This is in keeping with previous studies showing that pre-cleaved N-terminal OPN (containing the integrin binding sites) demonstrates increased adhesion over full-length wildtype OPN $[24,27,30]$. In contrast, the $468-\Delta \mathrm{TC}$ cells had decreased adhesive capabilities independent of thrombin or integrin blocking. Interestingly, the expression of the adhesion molecule MCAM by $468-\triangle \mathrm{TC}$ cells was also decreased significantly compared to 468-OPN cells. Loss of MCAM expression has been hypothesized to increase detachment of cells and therefore increase metastatic ability [35].

Urokinase plasminogen activator (uPA) is an important mediator of matrix degradation and invasiveness of cancer cells [36]. Both expression and activity of uPA was significantly elevated in $468-\Delta \mathrm{TC}$ cells. Also, expression of the uPA inhibitor and tumor suppressor maspin [37] was significantly higher in 468-OPN cells compared to 468- $\triangle \mathrm{TC}$ cells, consistent with the increased uPA expression and proteolytic activity in 468- $\Delta \mathrm{TC}$ cells observed in vitro and the increased metastasis observed in vivo. This suggests that $\Delta \mathrm{TC}$ OPN is capable of modulating several components of the uPA system. Wildtype OPN has previously been shown to increase uPA activity; however those studies used shorter treatments of exogenous OPN from 
various sources such as bacteria and human milk $[17,32,38,39]$ rather than endogenously expressed OPN. There is still uncertainty in the literature concerning the post-translational modifications of OPN, and specifically the differences in host versus tumor derived OPN [40], which may also account for differences in observed results.

Although in vitro functional assays help us to describe individual behaviors of cancer cells, the human body is a complex system. We therefore also compared the cell lines using in vivo mammary fat pad injections and spontaneous metastasis assays in nude mice. Previous studies have demonstrated that there is a role for OPN in in vivo primary tumor growth of multiple cancer types [41-46]. Specifically in breast cancer, there are numerous reports of OPN knockdown that lead to decreased in vivo tumor growth [47-49]. Previous studies from our group and others aimed at blocking OPN cleavage in vivo by pharmacologically inhibiting thrombin indicate that inhibition of thrombin can reduce malignant and metastatic behavior of breast cancer cells using both OPN-dependent and OPN-independent mechanisms $[24,50]$. The current study found that directly removing the thrombin cleavage domain from OPN produced significantly larger tumors in a shorter time span than wildtype OPN or control. Also, the growth rates (i.e. doubling time) were not significantly different, indicating that thrombin-uncleavable OPN may grant breast cancer cells an early advantage in tumor initiation. The cause of this early advantage could be linked to decreased apoptosis of the cells through decreased expression of the pro-apoptotic ligand TRAIL $[51,52]$. Mice injected with $468-\Delta \mathrm{TC}$ cells were also found to have increased metastatic burden to the lymph nodes indicating increased severity of metastasis. The increased activity of the uPA system could help the tumor metastasize more readily. In addition, the decreased adhesion and expression of MCAM in 468$\triangle \mathrm{TC}$ cells could also help to explain why there is an increased effect on lymph node metastasis.

The bulk of evidence concerning OPN function implicates the integrin binding domains in OPN-mediated tumorigenesis [14-18,20-24]. However, some studies show that it is the $\mathrm{C}$-terminal half of OPN, containing the CD44 binding domain, that is responsible for the protein's effects on cancer cells [31,53-55]. We hypothesize that deletion of the thrombin cleavage domain may be interrupting integrin binding of OPN and therefore it could be CD44 binding to OPN which may be causing the observed effects. Future studies to test this hypothesis are currently being investigated.

\section{Conclusions}

In summary, the novel findings presented here demonstrate that deletion of the thrombin cleavage domain from OPN decreases in vitro cell adhesion and in vivo primary tumor latency time, and increases in vitro uPA expression and activity as well as in vivo primary tumor growth and lymph node metastatic burden of MDAMB-468 breast cancer cells. To the best of our knowledge, this is the first study to specifically study the effects of OPN thrombin cleavage by site-directed mutagenesis. Taken together, the results presented here suggest that thrombin-uncleavable OPN conveys an early tumor formation advantage as well as a metastatic advantage, possibly due to increases in proteolytic activity and decreases in adhesion and apoptosis. Further studies are needed to clarify whether $\triangle \mathrm{TC}$-OPN is simply refractory to cleavage, or whether the deletion imparts some other additional effects such as altering the conformation of OPN and/or inhibiting an undefined interaction that in turn influence downstream functional cell behavior. Elucidation of the mechanisms responsible for these observations and the translation of this knowledge into the clinic could ultimately provide new therapeutic opportunities for combating breast cancer.

\section{Additional material}

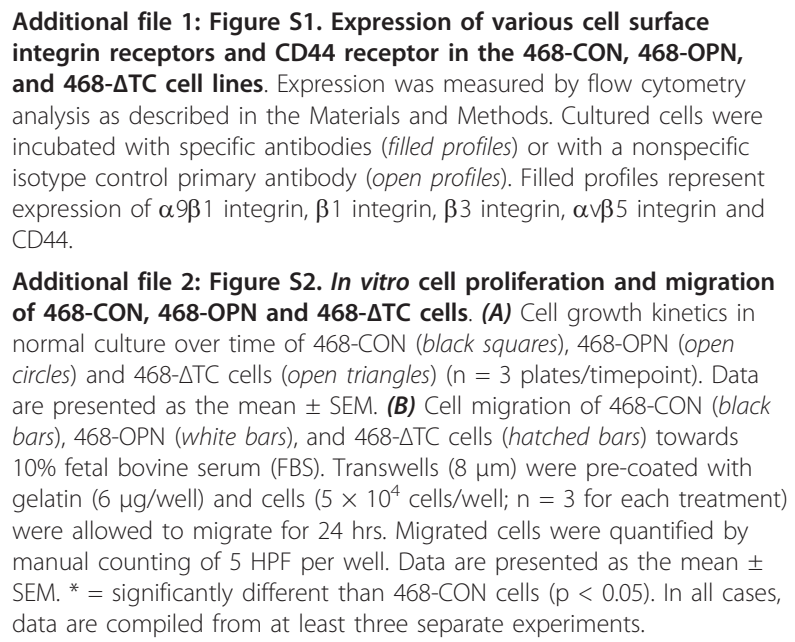

Additional file 2: Figure S2. In vitro cell proliferation and migration of $468-C O N, 468-O P N$ and $468-\Delta T C$ cells. $(A)$ Cell growth kinetics in normal culture over time of 468-CON (black squares), 468-OPN (open circles) and $468-\triangle T C$ cells (open triangles) ( $n=3$ plates/timepoint). Data are presented as the mean \pm SEM. (B) Cell migration of 468-CON (black bars), 468-OPN (white bars), and 468- $\triangle \mathrm{TC}$ cells (hatched bars) towards $10 \%$ fetal bovine serum (FBS). Transwells $(8 \mu \mathrm{m})$ were pre-coated with gelatin $(6 \mu \mathrm{g} /$ well $)$ and cells $\left(5 \times 10^{4}\right.$ cells/well; $n=3$ for each treatment) were allowed to migrate for 24 hrs. Migrated cells were quantified by manual counting of 5 HPF per well. Data are presented as the mean \pm SEM. ${ }^{*}=$ significantly different than $468-C O N$ cells $(p<0.05)$. In all cases, data are compiled from at least three separate experiments.

\section{Abbreviations}

468-CON: MDA-MB-468 cells stably transfected with a control vector; 468OPN: MDA-MB-468 cells stably transfected with wildtype osteopontin; 468$\triangle T C:$ MDA-MB-468 cells stably transfected with osteopontin containing a deleted thrombin cleave domain; aMEM: alpha minimum essential medium; ANOVA: analysis of variance; cDNA: complimentary deoxyribonucleic acid; DTT: dithiothreitol; EGFR: epidermal growth factor receptor; FBS: fetal bovine serum; GAPDH: glyceraldehyde 3-phosphate dehydrogenase; GLRSKS: glycine-leucine-arginine-serine-lysine-serine; H\&E: hematoxylin and eosin; HPF: high-powered field; HRP: horseradish peroxidase; IgG: immunoglobulin G; LN: Iymph node; MCAM: melanoma cell adhesion molecule; OPN: osteopontin; PBS: phosphate buffered saline; PCR: polymerase chain reaction; PE: phycoerytherin; RGB: red green blue; RGD: arginine-glycine-aspartic acid; RNA: ribonucleic acid; RSK: arginine-serine-lysine; SEM: standard error of the 
mean; SERPINB5: serine protease inhibitor B5; SDS: sodium dodecyl sulfate; SWYLR: serine-valine-valine-tyrosine-leucine-arginine; TBST: tris-buffered saline tween; TF: tissue factor; TRAIL: TNF-related apoptosis-inducing ligand; uPA: urokinase plasminogen activator; VN: vitronectin.

\section{Acknowledgements}

We thank Ann Chambers and Pieter Anborgh for helpful discussions and technical help related to the study. We also thank Ben Hedley for his help in carrying out and analyzing the flow cytometry studies, and Waleed Al-Katib for his assistance with the histopathological assessment of the in vivo metastasis studies. This work was supported in part by grants from the National Research Council of Canada (H.L. Holmes Award), the Schulich School of Medicine and Dentistry, and the Canada Foundation for Innovation (\#13199) (to ALA); and an award from the Lloyd Carr-Harris Foundation to A. Chambers and P. Anborgh. MSB was supported by graduate scholarships from the Canadian Institutes for Health Research (CIHR) Strategic Training Program and the Translational Breast Cancer Research Unit, London Regional Cancer Program. ALA is supported by a CIHR New Investigator Award and an Early Researcher Award from the Ontario Ministry of Research and Innovation.

\section{Author details}

'Department of Anatomy \& Cell Biology, Schulich School of Medicine and Dentistry, University of Western Ontario, (1151 Richmond Street), London Ontario, (N6A 3K7), Canada. ${ }^{2}$ Department of Oncology, Schulich School of Medicine and Dentistry, (790 Commissioners Road East), London Ontario, (N6A 4L6), Canada. ${ }^{3}$ London Regional Cancer Program, London Health Sciences Centre, (790 Commissioners Road East), London Ontario, (N6A 4L6), Canada. ${ }^{4}$ Lawson Health Research Institute, (375 South Street), London Ontario, (N6A 4G5), Canada.

\section{Authors' contributions}

MSB participated in the design of the study, carried out the majority of the experimental work, and drafted the manuscript. EBS contributed to the western blot analysis and the adhesion assays. DG performed the tumor cell injections for the in vivo mouse assays. COP carried out the histopathological sectioning and staining of mouse tissues. ALA conceived of the study, participated in its design and coordination, and helped to draft the manuscript. All authors read and approved the final manuscript.

\section{Competing interests}

The authors declare that they have no competing interests.

Received: 1 July 2010 Accepted: 19 January 2011

Published: 19 January 2011

\section{References}

1. Wai PY, Kuo PC: Osteopontin: Regulation in tumor metastasis. Cancer Metastasis Rev 2008, 27:103-118.

2. Bellahcene A, Castronovo V, Ogbureke KU, Fisher LW, Fedarko NS: Small integrin-binding ligand N-linked glycoproteins (SIBLINGs): Multifunctional proteins in cancer. Nat Rev Cancer 2008, 8:212-226.

3. Agrawal D, Chen T, Irby R, Quackenbush J, Chambers AF, Szabo M, Cantor A, Coppola D, Yeatman TJ: Osteopontin identified as colon cancer tumor progression marker. C R Biol 2003, 326:1041-1043.

4. Yeatman TJ, Chambers AF: Osteopontin and colon cancer progression. Clin Exp Metastasis 2003, 20:85-90.

5. Casson AG, Wilson SM, McCart JA, O'Malley FP, Ozcelik H, Tsao MS, Chambers AF: Ras mutation and expression of the ras-regulated genes osteopontin and cathepsin L in human esophageal cancer. Int J Cancer 1997, 72:739-745.

6. Ue T, Yokozaki H, Kitadai Y, Yamamoto S, Yasui W, Ishikawa T, Tahara E: Coexpression of osteopontin and CD44v9 in gastric cancer. Int J Cancer 1998, 79:127-132.

7. Gotoh M, Sakamoto M, Kanetaka K, Chuuma M, Hirohashi S: Overexpression of osteopontin in hepatocellular carcinoma. Pathol Int 2002, 52:19-24.

8. Chambers AF, Wilson SM, Kerkvliet N, O'Malley FP, Harris JF, Casson AG: Osteopontin expression in lung cancer. Lung Cancer 1996, 15:311-323.

9. Anborgh PH, Wilson SM, Tuck AB, Winquist E, Schmidt N, Hart R, Kon S, Maeda M, Uede T, Stitt LW, Chambers AF: New dual monoclonal ELISA for measuring plasma osteopontin as a biomarker associated with survival in prostate cancer: Clinical validation and comparison of multiple ELISAs. Clin Chem 2009, 55:895-903.

10. Thalmann GN, Sikes RA, Devoll RE, Kiefer JA, Markwalder R, Klima I, FarachCarson CM, Studer UE, Chung LW: Osteopontin: Possible role in prostate cancer progression. Clin Cancer Res 1999, 5:2271-2277.

11. Rudland PS, Platt-Higgins A, El-Tanani M, De Silva Rudland S, Barraclough R, Winstanley JH, Howitt R, West CR: Prognostic significance of the metastasis-associated protein osteopontin in human breast cancer. Cancer Res 2002, 62:3417-3427.

12. Singhal H, Bautista DS, Tonkin KS, O'Malley FP, Tuck AB, Chambers AF, Harris JF: Elevated plasma osteopontin in metastatic breast cancer associated with increased tumor burden and decreased survival. Clin Cancer Res 1997, 3:605-611.

13. Bramwell VH, Doig GS, Tuck AB, Wilson SM, Tonkin KS, Tomiak A, Perera F, Vandenberg TA, Chambers AF: Serial plasma osteopontin levels have prognostic value in metastatic breast cancer. Clin Cancer Res 2006, 12:3337-3343.

14. Furger KA, Menon RK, Tuck AB, Bramwell VH, Chambers AF: The functional and clinical roles of osteopontin in cancer and metastasis. Curr Mol Med 2001, 1:621-632.

15. Furger KA, Allan AL, Wilson SM, Hota C, Vantyghem SA, Postenka CO, AlKatib W, Chambers AF, Tuck AB: Beta(3) integrin expression increases breast carcinoma cell responsiveness to the malignancy-enhancing effects of osteopontin. Mol Cancer Res 2003, 1:810-819.

16. Tuck AB, Hota C, Wilson SM, Chambers AF: Osteopontin-induced migration of human mammary epithelial cells involves activation of EGF receptor and multiple signal transduction pathways. Oncogene 2003, 22:1198-1205.

17. Tuck AB, Hota C, Chambers AF: Osteopontin(OPN)-induced increase in human mammary epithelial cell invasiveness is urokinase (UPA)dependent. Breast Cancer Res Treat 2001, 70:197-204.

18. Tuck AB, Elliott BE, Hota C, Tremblay E, Chambers AF: Osteopontininduced, integrin-dependent migration of human mammary epithelial cells involves activation of the hepatocyte growth factor receptor (met). J Cell Biochem 2000, 78:465-475.

19. Khan SA, Cook AC, Kappil M, Günthert U, Chambers AF, Tuck AB, Denhardt DT: Enhanced cell surface CD44 variant (v6, v9) expression by osteopontin in breast cancer epithelial cells facilitates tumor cell migration: Novel post-transcriptional, post-translational regulation. Clin Exp Metastasis 2005, 22:663-673.

20. Cook AC, Tuck AB, McCarthy S, Turner JG, Irby RB, Bloom GC, Yeatman TJ, Chambers AF: Osteopontin induces multiple changes in gene expression that reflect the six "hallmarks of cancer" in a model of breast cancer progression. Mol Carcinog 2005, 43:225-236.

21. Allan AL, George R, Vantyghem SA, Lee MW, Hodgson NC, Engel CJ, Holliday RL, Girvan DP, Scott LA, Postenka CO, Al-Katib W, Stitt LW, Uede T, Chambers AF, Tuck AB: Role of the integrin-binding protein osteopontin in lymphatic metastasis of breast cancer. Am J Pathol 2006, 169:233-246.

22. Tuck AB, Chambers AF, Allan AL: Osteopontin overexpression in breast cancer: Knowledge gained and possible implications for clinical management. J Cell Biochem 2007, 102:859-868.

23. Adwan H, Bauerle T, Najajreh Y, Elazer V, Golomb G, Berger MR: Decreased levels of osteopontin and bone sialoprotein II are correlated with reduced proliferation, colony formation, and migration of GFP-MDA-MB231 cells. Int J Oncol 2004, 24:1235-1244.

24. Schulze EB, Hedley BD, Goodale D, Postenka CO, Al-Katib W, Tuck AB, Chambers AF, Allan AL: The thrombin inhibitor argatroban reduces breast cancer malignancy and metastasis via osteopontin-dependent and osteopontin-independent mechanisms. Breast Cancer Res Treat 2008, 112:243-254.

25. Cook AC, Chambers AF, Turley EA, Tuck AB: Osteopontin induction of hyaluronan synthase 2 expression promotes breast cancer malignancy. J Biol Chem 2006, 281:24381-24389.

26. Kon S, Yokosaki Y, Maeda M, Segawa T, Horikoshi Y, Tsukagoshi H, Rashid MM, Morimoto J, Inobe M, Shijubo N, Chambers AF, Uede T: Mapping of functional epitopes of osteopontin by monoclonal antibodies raised against defined internal sequences. J Cell Biochem 2002, 84:420-432.

27. Senger DR, Perruzzi CA: Cell migration promoted by a potent GRGDScontaining thrombin-cleavage fragment of osteopontin. Biochim Biophys Acta 1996, 1314:13-24. 
28. Vine AK: Recent advances in haemostasis and thrombosis. Retina 2009, 29:1-7.

29. Rak J, Milsom C, Magnus N, Yu J: Tissue factor in tumour progression. Best Pract Res Clin Haematol 2009, 22:71-83.

30. Senger DR, Brown LF, Perruzzi CA, Papadopoulos-Sergiou A, Van de Water $\mathrm{L}$ : Osteopontin at the tumor/host interface. functional regulation by thrombin-cleavage and consequences for cell adhesion. Ann N Y Acad Sci 1995, 760:83-100.

31. Mi Z, Oliver T, Guo H, Gao C, Kuo PC: Thrombin-cleaved $\mathrm{COOH}(-)$ terminal osteopontin peptide binds with cyclophilin C to CD147 in murine breast cancer cells. Cancer Res 2007, 67:4088-4097.

32. Tuck AB, Arsenault DM, O'Malley FP, Hota C, Ling MC, Wilson SM, Chambers AF: Osteopontin induces increased invasiveness and plasminogen activator expression of human mammary epithelial cells. Oncogene 1999, 18:4237-4246.

33. Young MF, Kerr JM, Termine JD, Wewer UM, Wang MG, McBride OW, Fisher LW: cDNA cloning, mRNA distribution and heterogeneity, chromosomal location, and RFLP analysis of human osteopontin (OPN). Genomics 1990, 7:491-502.

34. Kon S, Maeda M, Segawa T, Hagiwara Y, Horikoshi Y, Chikuma S, Tanaka K, Rashid MM, Inobe M, Chambers AF, Uede T: Antibodies to different peptides in osteopontin reveal complexities in the various secreted forms. J Cell Biochem 2000, 77:487-498.

35. Ouhtit A, Gaur RL, Abd Elmageed ZY, Fernando A, Thouta R, Trappey AK, Abdraboh ME, El-Sayyad HI, Rao P, Raj MG: Towards understanding the mode of action of the multifaceted cell adhesion receptor CD146. Biochim Biophys Acta 2009, 1795:130-136.

36. Chabottaux V, Noel A: Breast cancer progression: Insights into multifaceted matrix metalloproteinases. Clin Exp Metastasis 2007, 24:647-656.

37. Al-Ayyoubi M, Schwartz BS, Gettins PG: Maspin binds to urokinase-type and tissue-type plasminogen activator through exosite-exosite interactions. J Biol Chem 2007, 282:19502-19509.

38. Das R, Mahabeleshwar GH, Kundu GC: Osteopontin stimulates cell motility and nuclear factor kappaB-mediated secretion of urokinase type plasminogen activator through phosphatidylinositol 3-kinase/Akt signaling pathways in breast cancer cells. J Biol Chem 2003, 278:28593-28606.

39. Das R, Mahabeleshwar GH, Kundu GC: Osteopontin induces AP-1mediated secretion of urokinase-type plasminogen activator through c-src-dependent epidermal growth factor receptor transactivation in breast cancer cells. J Biol Chem 2004, 279:11051-11064.

40. Crawford HC, Matrisian LM, Liaw L: Distinct roles of osteopontin in host defense activity and tumor survival during squamous cell carcinoma progression in vivo. Cancer Res 1998, 58:5206-5215.

41. Cui R, Takahashi F, Ohashi R, Gu T, Yoshioka M, Nishio K, Ohe Y, Tominaga S, Takagi Y, Sasaki S, Fukuchi Y, Takahashi K: Abrogation of the interaction between osteopontin and alphavbeta3 integrin reduces tumor growth of human lung cancer cells in mice. Lung Cancer 2007, 57:302-310.

42. Hirama M, Takahashi F, Takahashi K, Akutagawa S, Shimizu K, Soma S, Shimanuki Y, Nishio K, Fukuchi Y: Osteopontin overproduced by tumor cells acts as a potent angiogenic factor contributing to tumor growth. Cancer Lett 2003, 198:107-117.

43. Hsieh YH, Juliana MM, Hicks PH, Feng G, Elmets C, Liaw L, Chang PL: Papilloma development is delayed in osteopontin-null mice: Implicating an antiapoptosis role for osteopontin. Cancer Res 2006, 66:7119-7127.

44. Khodavirdi AC, Song Z, Yang S, Zhong C, Wang S, Wu H, Pritchard C, Nelson PS, Roy-Burman P: Increased expression of osteopontin contributes to the progression of prostate cancer. Cancer Res 2006, 66:883-888.

45. Philip S, Bulbule A, Kundu GC: Osteopontin stimulates tumor growth and activation of promatrix metalloproteinase-2 through nuclear factorkappa B-mediated induction of membrane type 1 matrix metalloproteinase in murine melanoma cells. J Biol Chem 2001, 276:44926-44935.

46. Senger DR, Perruzzi CA, Gracey CF, Papadopoulos A, Tenen DG: Secreted phosphoproteins associated with neoplastic transformation: Close homology with plasma proteins cleaved during blood coagulation. Cancer Res 1988, 48:5770-5774.
47. Behrend El, Craig AM, Wilson SM, Denhardt DT, Chambers AF: Reduced malignancy of ras-transformed NIH 3 T3 cells expressing antisense osteopontin RNA. Cancer Res 1994, 54:832-837.

48. Shevde LA, Samant RS, Paik JC, Metge BJ, Chambers AF, Casey G, Frost AR, Welch DR: Osteopontin knockdown suppresses tumorigenicity of human metastatic breast carcinoma, MDA-MB-435. Clin Exp Metastasis 2006, 23:123-133.

49. Su L, Mukherjee AB, Mukherjee BB: Expression of antisense osteopontin RNA inhibits tumor promoter-induced neoplastic transformation of mouse JB6 epidermal cells. Oncogene 1995, 10:2163-2169.

50. Hu L, Lee M, Campbell W, Perez-Soler R, Karpatkin S: Role of endogenous thrombin in tumor implantation, seeding, and spontaneous metastasis. Blood 2004, 104:2746-2751.

51. Ashkenazi A, Pai RC, Fong S, Leung S, Lawrence DA, Marsters SA, Blackie C, Chang L, McMurtrey AE, Hebert A, DeForge L, Koumenis IL, Lewis D, Harris L, Bussiere J, Koeppen H, Shahrokh Z, Schwall RH: Safety and antitumor activity of recombinant soluble Apo2 ligand. J Clin Invest 1999, 104:155-162

52. Wiley SR, Schooley K, Smolak PJ, Din WS, Huang CP, Nicholl JK, Sutherland GR, Smith TD, Rauch C, Smith CA: Identification and characterization of a new member of the TNF family that induces apoptosis. Immunity 1995, 3:673-682.

53. Lin YH, Yang-Yen HF: The osteopontin-CD44 survival signal involves activation of the phosphatidylinositol 3-kinase/Akt signaling pathway. J Biol Chem 2001, 276:46024-46030.

54. Teramoto H, Castellone MD, Malek RL, Letwin N, Frank B, Gutkind JS, Lee NH: Autocrine activation of an osteopontin-CD44-rac pathway enhances invasion and transformation by H-RasV12. Oncogene 2005, 24:489-501.

55. Shao J, Washington MK, Saxena R, Sheng H: Heterozygous disruption of the PTEN promotes intestinal neoplasia in APCmin/+ mouse: Roles of osteopontin. Carcinogenesis 2007, 28:2476-2483.

\section{Pre-publication history}

The pre-publication history for this paper can be accessed here: http://www.biomedcentral.com/1471-2407/11/25/prepub

doi:10.1186/1471-2407-11-25

Cite this article as: Beausoleil et al.: Deletion of the thrombin cleavage domain of osteopontin mediates breast cancer cell adhesion, proteolytic activity, tumorgenicity, and metastasis. BMC Cancer 2011 11:25.

\section{Submit your next manuscript to BioMed Central and take full advantage of:}

- Convenient online submission

- Thorough peer review

- No space constraints or color figure charges

- Immediate publication on acceptance

- Inclusion in PubMed, CAS, Scopus and Google Scholar

- Research which is freely available for redistribution

Submit your manuscript at www.biomedcentral.com/submit
C) Biomed Central 